\title{
PERAN KEPERCAYAAN MEMEDIASI CITRA MEREK TERHADAP NIAT BELI PADA PRODUK SMARTPHONE SAMSUNG DI KOTA DENPASAR
}

\section{Luh Gede Dian Anggara Putri ${ }^{1}$ I Putu Gde Sukaatmadja ${ }^{2}$}

\author{
${ }^{1,2}$ Fakultas Ekonomi dan Bisnis Universitas Udayana (Unud), Bali, Indonesia
} e-mail: danggaraputri@gmail.com

\begin{abstract}
ABSTRAK
Perkembangan teknologi di era globalisasi membawa banyak perubahan, ditandai dengan hadirnya smartphone. Salah satu merek yang beredar di pasar Indonesia adalah Smartphone Samsung. Penelitian ini bertujuan untuk menjelaskan pengaruh citra merek dan kepercayaan terhadap niat beli, serta peran kepercayaan memediasi pengaruh citra merek terhadap niat beli smartphone Samsung di Kota Denpasar. Ukuran sampel sebanyak 110 orang. Data diperoleh dengan melakukan penyebaran kuesioner menggunakan skala Likert. Penelitian ini menggunakan teknik analisis jalur serta uji sobel. Hasil dari penelitian ini menunjukkan bahwa citra merek berpengaruh positif signifikan terhadap niat beli. Citra merek berpengaruh positif signifikan terhadap kepercayaan. Kepercayaan berpengaruh positif signifikan terhadap niat beli. Hasil menunjukkan kepercayaan secara positif serta signifikan dapat memediasi pengaruh citra merek terhadap niat beli.
\end{abstract}

Kata Kunci: citra merek, kepercayaan, dan niat beli.

\begin{abstract}
Technological developments in the era of globalization brought many changes, marked by presence of smartphone. One brand in the market Indonesia is smartphone Samsung. This study aimed to determine the effect of brand image and trust in the purchase intention, as well as the role of trust mediating influence on purchase intention of brand image onproducts smartphone the Samsung in Denpasar city. The study was conducted in Denpasar, using a sample size of 110 people. The questionnaires used Likert scale. Path analysis techniques incorporating Sobel test to analyzing the data. The results of this study indicate that the brand image positive significant impact on purchase intentions. Brand image has positive effect on trust significantly. Trust positive significant impact on purchase intentions. In addition, this study also showed that a positive significant trust mediating influence on the brand image and purchase intentions.
\end{abstract}

Keywords: brand image, trust and purchase intentions. 


\section{PENDAHULUAN}

Perkembangan teknologi di era globalisasi kini menjadi semakin pesat di berbagai belahan dunia. Perkembangan teknologi ini tidak lepas dari semakin kompleks kegiatan manusia saat ini. Semakin kompleksnya kegiatan manusia mendorong semakin beragam kebutuhan yang diperlukan. Manusia menggunakan akal guna mendapatkan solusi untuk kebutuhannya beragam tersebut. Beragamnya kebutuhan manusia tersebut akan mendorong akal manusia mencari ide baru.

Perkembangan teknologi dan informasi yang berkembang sekarang ini mengubah beberapa pola aspek kehidupan manusia salah satunya dalam penggunaan perangkat komunikasi. Perangkat telekomunikasi saat ini telah berevolusi yang ditandai dengan hadirnya sebuah smartphone dengan berbagai sistem operasinya yang memudahkan pekerjaan manusia. Smartphone muncul sebagai alat pendukung menggeser komputer, laptop, tablet, dan telepon seluler biasa. Kemajuan teknologi sekarang ini memunculkan berbagai pilihan alat baru yang menonjol pada smartphone seperti aplikasi-aplikasi sosial media misalnya Instagram, Line, Twitter, dan Facebook yang berkembang di seluruh dunia termasuk di Indonesia (Dharma dan Sukaatmadja, 2015).

Survei yang diselenggarakan oleh APJII (Asosiasi Penyelenggara Jasa Internet Indonesia) tahun 2016 menunjukkan bahwa sekitar 67,8\% atau 89,9 juta orang di Indonesia mempergunakan perangkat smartphone dalam kegiatan komunikasi sehari-hari serta akses internet, seperti tersaji pada Tabel 1. berikut ini. 
Tabel 1.

Pengguna Perangkat Telekomunikasi di Indonesia

\begin{tabular}{lcc}
\hline $\begin{array}{c}\text { Pengguna Perangkat } \\
\text { Telekomunikasi }\end{array}$ & $\begin{array}{c}\text { Pengguna } \\
\text { (juta) }\end{array}$ & Persentase \\
\hline Smartphone & 89,9 & 67,8 \\
Komputer & 19,5 & 14,7 \\
Laptop & 16,7 & 12,6 \\
Tablet & 5 & 3,8 \\
Lainnya & 1,5 & 1,1 \\
\hline Jumlah & $\mathbf{1 3 2 , 6}$ & $\mathbf{1 0 0}$ \\
\hline Sumber: APJII (Asosiasi Penyelenggara Jasa Internet Indonesia), 2016
\end{tabular}

Berdasarkan Tabel 1. menunjukkan bahwa tingginya pengguna perangkat telekomunikasi smartphone di Indonesia memunculkan peluang bisnis, dimana sekarang ini banyak perusahaan yang berkompetisi menciptakan produk-produk handal yang memenuhi kebutuhan dan keinginan konsumen yang mengikuti permintaan pasar. Masing-masing perusahaan dituntut untuk memiliki spesifikasi di dalam produknya sehingga dapat tetap hidup dan bersaing di pasaran. Saat ini, kesadaran konsumen akan informasi mengenai merek yang titawarkan lebih tinggi akibat persaingan pasar yang terbuka.

Pasar di Indonesia saat ini ada beberapa merek perusahaan smartphone diantaranya Samsung, Apple, Huawei, OPPO, Vivo, dan lainnya. Banyaknya perusahaan smartphone di Indonesia tetap memunculkan satu nama yang memiliki market share terbesar, yaitu Samsung terlihat pada Tabel 2.

Tabel 2.

Market Share Smartphone Tahun 2016 di Indonesia

\begin{tabular}{cccccccc}
\hline Periode & Samsung & Apple & $\begin{array}{c}\text { Huawei } \\
(\boldsymbol{\%})\end{array}$ & OPPO & Vivo & Lainnya & Total \\
\hline 2016 Q1 & 23,8 & 15,4 & 8,4 & 5,9 & 4,4 & 42,1 & 100 \\
2016 Q2 & 22,7 & 11,7 & 9,3 & 6,6 & 4,8 & 44,9 & 100 \\
2016 Q3 & 20,9 & 12,5 & 9,3 & 7,1 & 5,9 & 44,3 & 100 \\
2016 Q4 & 18,0 & 18,2 & 10,5 & 7,3 & 5,7 & 40,3 & 100 \\
2017 Q1 & 23,3 & 14,7 & 10,0 & 7,5 & 5,5 & 39,0 & 100 \\
\hline Sumber: IDC (International Data Corpuration), 2017 &
\end{tabular}


Berdasarkan Tabel 2. menunjukkan bahwa smartphone Samsung selalu memiliki market share tertinggi dibandingkan pesaingnya. Meskipun Samsung memiliki market share terbesar di pasar, tetapi tidak menjamin produk tersebut tidak luput dari kesalahan. Fenomena yang terjadi belakangan ini berbagai tipe smartphone keluaran Samsung mengalami permasalahan yang merugikan konsumen penggunanya. Berdasarkan laman liputan6.com berbagai tipe Samsung meledak di berbagai belahan dunia salah satunya di Indonesia. Permasalahan yang ada pada smartphone Samsung ini tentu akan berpengaruh terhadap citra merek, kepercayaan, serta niat beli konsumen. Survei yang dilakukan oleh top brand award 2017 fase 1 menunjukkan hasil yang berbeda pada Tabel 3.

Tabel 3.

Top Brand Index Kategori Telekomunikasi Smartphone

\begin{tabular}{lcc}
\hline & Merek & TBI \\
& & $(\%)$ \\
\hline Samsung & & 46,4 \\
Nokia & 8,8 \\
Blackberry & 8,0 \\
Apple & 5,1 \\
Smartfren & & 5,1 \\
Lenovo & 4,4 \\
Oppo & 4,1 \\
Asus & Total & 3,8 \\
Lainnya & 14,3 \\
\hline
\end{tabular}

Sumber: TBI (Top Brand Index), 2017

Berdasarkan persentase di atas menunjukkan bahwa smartphone Samsung tetap menjadi primadona di mata konsumen meskipun telah mengalami beberapa masalah yang merugikan konsumen. Citra merek yang selama ini dimiliki oleh smartphone Samsung dimata konsumen adalah baik. Citra merek dibangun berdasarkan kesan, pemikiran, ataupun pengalaman yang dialami seseorang terhadap suatu merek yang pada akhirnya akan membentuk sikap terhadap merek 
yang bersangkutan (Setiadi, 2003:180). Merek meningkatkan pertambahan nilai kekayaan dengan menarik serta menumbuhkan loyalitas pelanggan sebagai hasil dari produk yang khas serta kombinasi produk secara efektif dalam mempertahankan nilai tambah pada benak konsumen, (Walley et al., 2007). Surachman (2008:275) menyatakan bahwa masyarakat memiliki pandangan yang berbeda di benaknya terhadap suatu merek yang disebut citra merek. Kotler dan Keller (2009:266) menyatakan bahwa di benak konsumen terdapat kepercayaan dan pengelihatan yang tersembunyi yang direalisasikan dalam ingatan konsumen yang disebut dengan citra merek.

Ingatan-ingatan konsumen terhadap suatu merek yang merupakan kumpulan kesan yang ada di benak konsumen mengenai suatu merek dapat dikatakan sebagai citra merek (Rizan dkk., 2012). Citra konsumen yang positif mengenai merek tertentu dapat mempengaruhi bagaimana keputusan konsumen untuk melakukan pembelian (Permadi dkk., 2014). Menurut Bastian (2014) serta Dharma dan Sukaatmadja (2015) menyebutkan faktor-faktor yang menjadi tolok ukur citra merek yakni atribut suatu produk (product atributes), manfaat konsumen (consumer benefit), kepribadian merek (brand personality) serta sikap suatu merek (brand attitude).

Selain citra merek, kepercayaan juga turut andil dalam memunculkan niat beli seseorang terhadap suatu merek atau produk tertentu. Albari dan Liriswati (2004), di mana norma subyektifnya adalah variabel kepercayaan merek dan sikap. Arista dan Astuti (2011) menyatakan bahwa karena adanya keinginan dan kebutuhan konsumen sehingga mengharapkan pihak lain akan dapat memenihinya 
maka terbangunlah sebuah kepercayaan. Rizan dkk. (2012) menyatakan bahwa konsumen bersedia menanggung segala resiko yang diakibatkan oleh suatu merek karena adanya harapan konsumen pada merek tersebut yang akan memberikan hasil positif sehingga membuat konsumen setia karena telah memiliki kepercayaan pada merek tersebut. Efriandy (2013) menyatakan bahwa kepercayaan memiliki hubungan dengan perasaan seseorang terhadap objek tertentu yang memiliki banyak pertimbangan di dalamnya. Kristianto dan Junaedi (2014) mengartikan kepercayaan merupakan suatu keinginan untuk saling mempercayai antar relasi. Kepercayaan yang dimiliki konsumen merupakan pengetahuan atau ilmu sedangkan atribut, objek dan manfaatnya merupakan kesimpulan dari pengetahuan tersebut (Mowen dan Minor 2002:312). Menurut Ika dan Kustini (2011), kepercayaan dapat diukur melalui beberapa indikator antara lain merasa aman dalam menggunakan produk dan memberi kemudahan yang lebih jika menggunakan produk. Selanjutnya menurut Chen dan Chang (2012), terdapat indikator lain yang dapat digunakan untuk mengukur kepercayaan, yaitu kepercayaan akan reputasi yang baik serta kepercayaan akan keandalan kerja. Apabila citra merek suatu merek atau produk sudah baik di mata konsumen maka konsumen akan memiliki kepercayaan terhadap suatu merek atau produk dan pada akhirnya akan memunculkan niat beli.

Arista dan Astuti (2011) menyatakan bahwa niat beli terbentuk atas proses ingin tahu dalam pikiran yang membentuk sebuah pemahaman dan proses belajar. Menurut Shah et al. (2012), niat pembelian adalah jenis keputusan yang mempelajari secara khusus mengapa konsumen membeli sebuah merek. Niat beli 
dapat diukur melalui pertimbangan merek melakukan pembelian dan harapan melakukan pembelian produk itu pada masa depan (Bagram dan Khan., 2012). Fure (2013) menyatakan bahwa niat merupakan suatu perilaku yang dimiliki oleh konsumen yang mendasari suatu keputusan pembelian yang hendak dilakukan. Tariq et al. (2013) menyatakan empat perilaku konsumen yang berhubungan dengan niat beli, seperti merencanakan membeli produk tetapi ragu, membulatkan tekad melakukan pembelian pada suatu produk, memikirkan membeli produk di masa yang akan datang dan melakukan pembelian sesungguhnya di masa yang akan datang. Menurut Schiffman dan Kanuk (2004) serta Gunawan dan Dharmayanti (2014), indikator dalam minat beli seorang konsumen yakni ketertarikan mencari informasi yang lebih mengenai suatu produk, pertimbangan untuk melakukan upaya pembelian, keinginan untuk mencari tahu informasi produk, ketertarikan untuk mencoba mengonsumsi serta keinginan untuk dapat memiliki produk. Penelitian mengenai peran kepercayaan memediasi citra merek terhadap niat beli pada produk smartphone Samsung di Kota Denpasar sangat menarik untuk dilakukan mengingat ketatnya persaingan bisnis antara merek satu dengan lainnya. Penelitian dalam topik ini menggunakan sampel calon konsumen smartphone Samsung di Kota Denpasar, untuk mengetahui peran kepercayaan memediasi citra merek terhadap niat beli masyarakat.

Berdasarkan latar belakang yang telah diuraikan di atas, dirumuskan apa saja rumusan masalah yang akan dikaji dalam penelitian yakni bagaimanakah pengaruh citra merek terhadap niat beli pada produk smartphone Samsung di Kota Denpasar, bagaimana pengaruh citra merek terhadap kepercayaan pada produk 
smartphone Samsung di Kota Denpasar, bagaimana pengaruh kepercayaan terhadap niat beli pada produk smartphone Samsung di Kota Denpasar, bagaimana peran kepercayaan memediasi citra merek terhadap niat beli pada produk smartphone Samsung di Kota Denpasar.

Berdasarkan rumusan masalah tersebut, maka tujuan penelitian dalam penelitian ini yaitu menjelaskan pengaruh citra merek terhadap niat beli pada smartphone Samsung di Kota Denpasar, menjelaskan pengaruh citra merek terhadap kepercayaan pada smartphone Samsung di Kota Denpasar, menjelaskan pengaruh kepercayaan terhadap niat beli pada smartphone Samsung di Kota Denpasar, menjelaskan peran kepercayaan memediasi citra merek terhadap niat beli pada smartphone Samsung di Kota Denpasar. Berdasarkan tujuan penelitian tersebut, penelitian ini diharapkan dapat memberikan manfaat yaitu penelitian ini diharapkan dapat menambah bukti empiris mengenai pengaruh antara variabel citra merek, kepercayaan, dan niat beli. Diharapkan dalam penelitian ini dapat menjadi suatu contoh, memberi saran, dan menjadi referensi untuk penelitian lainnya yang akan ada selanjutnya. Bagi pihak smartphone Samsung ketika hendak mengambil pertimbangan dan keputusan untuk meningkatkan citra merek yang akan menumbuhkan rasa percaya di pikiran konsumen sehingga dapat meningkatkan niat untuk membeli produk smartphone Samsung diharapkan mendapatkan informasi yang dibutuhkan dalam penelitian ini.

Terdapat empat hipotesis yang dapat disusun dari penelitian ini yang dijelaskan sebagai berikut. Wang dan Tsai (2014) menyatakan bahwa niat pembelian memang benar ditingkatkan karena adanya citra merek yang tinggi 
pula. Wahyuni dan Suparna (2014) menyatakan bahwa niat beli produk tas tiruan dipengaruhi oleh adanya citra merek. Penelitian yang dilakukan Mendrofa (2012) di Surabaya juga menyatakan bahwa pengaruh positif yang citra merek terhadap niat beli pada produk laptop, hal ini menunjukkan bahwa semakin positif citra merek maka semakin tinggi intensi pembelian konsumen.

$\mathrm{H}_{1}$ : Citra merek berpengaruh positif signifikan terhadap niat beli

Citra merek yang baik sangat penting untuk meningkatkan kepercayaan konsumen terhadap sebuah produk. Penelitian terdahulu yang dilakukan Chen (2010) menyatakan kepercayaan dipengaruhi secara positif signifikan oleh citra merek. Lee (2011) menunjukkan bahwa citra merek memiliki dampak positif signifikan terhadap kepercayaan merek. Citra dan Santoso (2016) menyatakan bahwa citra merek berpengaruh positif terhadap kepercayaan merek. Berdasarkan hasil-hasil penelitian terdahulu yang memperoleh hasil positif disusun hipotesis yakni:

$\mathrm{H}_{2}$ : Citra merek berpengaruh positif signifikan terhadap kepercayaan

Arista dan Astuti (2011), Nusarika dan Purnami (2015), Citra dan Santoso (2016) menyatakan niat beli dipengaruhi secara positif signifikan oleh kepercayaan. Bertolak belakang dengan penelitian yang dilakukan oleh Rizanata (2014) yakni kepercayaan pelanggan tidak secara signifikan mempengaruhi niat beli pelanggan. Kepercayaan tidak memiliki hubungan yang signifikan dengan variabel niat pembelian hijau (Irandust dan Bamdad 2014).

$\mathrm{H}_{3}$ : Kepercayaan berpengaruh positif signifikan terhadap niat beli 
Diperlukan kepercayaan ketika timbulnya niat beli konsumen terhadap produk yang dinyatakan oleh Ling et al. (2010). Indraswari dan Pramudana (2014) menyatakan bahwa semakin banyak kepercayaan yang dimiliki maka akan menimbulkan niat beli yang semakin besar pula. Berdasarkan hasil penelitian Bastian (2014) menyatakan bahwa kepercayaan mempunyai pengaruh signifikan dan positif terhadap citra merek, artinya citra merek ADES PT Ades Alfindo Putra Setia akan memberikan kepercayaan yang baik bagi konsumen. Citra dan Santoso (2016) menyatakan bahwa kepercayaan positif signifikan mampu memediasi citra merek terhadap keputusan pembelian.

$\mathrm{H}_{4}$ : Kepercayaan secara positif signifikan mampu memediasi pengaruh variabel citra merek terhadap niat beli.

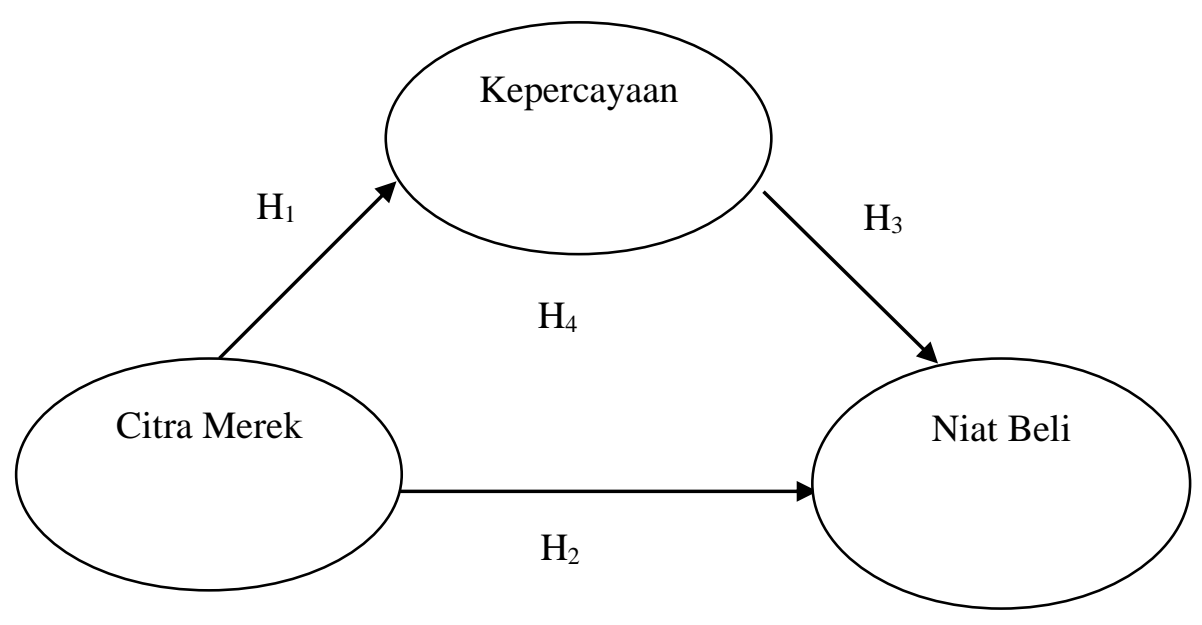

Gambar 1. Model Kerangka Konseptual

Sumber: Citra dan Santoso, 2016

\section{METODE PENELITIAN}

Penelitian ini masuk dalam kategori penelitian asosiatif, yang memiliki tujuan penelitian yaitu untuk mengetahui pengaruh sebab akibat dari variabel yang 
diteliti (Sugiyono, 2017:37). Penelitian dilakukan di Kota Denpasar dikarena melihat dari demografi masyarakat yang tinggal berasal dari berbagai daerah di Bali, sehingga secara umum dapat dikatakan mewakili masyarakat Bali. Terdapat tiga variabel yang dapat dikaji yakni variabel eksogen $(\mathrm{X})$, yaitu variabel yang dapat memberikan pengaruh kepada variabel lain tetapi tidak dapat dipengaruhi oleh variabel lain yang ada di dalam penelitian. Citra merek merupakan variabel eksogen dalam penelitian ini. Variabel intervening atau variabel mediasi $\left(\mathrm{Y}_{1}\right)$, merupakan variabel yang memiliki dua peran dan sebagai jembatan hubungan antara variabel eksogen dengan variabel endogen. Kepercayaan merupakan variabel intervening dalam penelitian ini. Variabel endogen $\left(\mathrm{Y}_{2}\right)$ merupakan variabel yang terpengaruh atau yang menjadi pelabuhan dari variabel eksogen. Niat beli merupakan variabel endogen dalam penelitian ini.

Penelitian ini menggunakan sampel adalah sebanyak 110 responden dengan kriteria penentuan sampel adalah sebagai berikut. Berpendidikan minimal SMA/SMK sederajat, bertempat tinggal di Kota Denpasar, belum pernah melakukan pembelian pada produk smartphone Samsung dan berniat membeli produk smartphone Samsung.

Penelitian ini menggunakan metode pengumpulan data dengan cara metode survei yakni dengan kuesioner. Kuesioner disebarkan pada seputaran wilayah Kota Denpasar dan pengisiannya didampingi oleh peneliti. Pengukuran atas jawaban dari responden diukur dengan menggunakan Skala Likert. Sangat setuju sampai sangat tidak setuju digunakan untuk menjawab setiap pertanyaan dari 
kuesioner. penelitian ini memberikan skor dari masing-masing pertanyaan diberikan agar mempermudah perhitungannya.

Sumber data primer dan sumber data sekunder yang dijadikan sumber data dalam penelitian ini. Responden merupan sumber data primer dalam penelitian ini. Kuesioner yang dibagikan terkait variabel diberikan tanggapan oleh responden. Pihak yang mempublikasikan data-data yang berhubungan dengan penelitian ini serta pihak yang menyediakan data merupakan sumber data sekunder seperti APJII, IDC, dan Top Brand Award Indonesia.

Alat pengumpulan data dalam penelitian ini berupa kuesioner, sehingga dengan begitu uji validitas dan reliabilitas perlu dilakukan agar kuesioner memang layak untuk dipergunakan. Analisis statistik deskriptif dan analisis statistik infrensial merupakan teknik analisis data yang digunakan yang terdiri atas uji asumsi klasik (uji normalitas, uji multikolinieritas, dan uji heteroskedastisitas), teknik analsis jalur (path analysis), dan uji sobel.

\section{HASIL DAN PEMBAHASAN}

Responden dalam penelitian ini menurut sampel sebanyak 104 responden, namun dalam penelitian dibulatkan ke atas menjadi 110 responden. Kriteria yang telah ditetapkan dan dipenuhi oleh responden yang telah berpartisipasi memberikan tanggapan pada kuesioner dalam penelitian ini yaitu diantaranya berdomisili di Kota Denpasar, berpendidikan minimal SMA/SMK sederajat, belum pernah melakukan pembelian pada produk smartphone Samsung dan berniat membeli produk smartphone Samsung. 


\section{Hasil Pengujian Instrumen}

Pengujian validitas indikator variabel dilihat dari nilai Pearson nya apabila nilai jika korelasi antara skor faktor dengan skor total bernilai positif dan nilainya lebih dari 0,30 (r > 0,3) maka instrument dapat dikatakan valid. Berdasarkan Tabel 4. seluruh indikator pernyataan memiliki tingkat korelasi melebihi 0,30 maka dari itu dapat disimpulkan memenuhi syarat validitas.

Tabel 4.

Hasil Uji Validitas

\begin{tabular}{|c|c|c|c|}
\hline Variabel & Indikator & $\begin{array}{c}\text { Pearson } \\
\text { Correlation }\end{array}$ & Keterangan \\
\hline Citra Merek (X) & $\begin{array}{ll}\text { 1. } & \text { Product Attributes (X1.1) } \\
\text { 2. } & \text { Consumer Benefits (X1.2) } \\
\text { 3. } & \text { Brand Personality (X1.3) } \\
\text { 4. } & \text { Brand Attitude (X1.4) }\end{array}$ & $\begin{array}{l}0,824 \\
0,924 \\
0,919 \\
0,616\end{array}$ & $\begin{array}{l}\text { Valid } \\
\text { Valid } \\
\text { Valid } \\
\text { Valid }\end{array}$ \\
\hline \multirow[t]{4}{*}{ Kepercayaan $\left(\mathrm{Y}_{1}\right)$} & $\begin{array}{l}\text { 1. Merasa aman menggunakan } \\
\text { produk (Y1.1) } \\
\text { 2. Memberi kemudahan yang }\end{array}$ & 0,729 & Valid \\
\hline & $\begin{array}{l}\text { lebih jika menggunakan } \\
\text { produk (Y1.2) }\end{array}$ & 0,772 & Valid \\
\hline & $\begin{array}{l}\text { 3. Kepercayaan memiliki reputasi } \\
\text { baik (Y1.3) }\end{array}$ & 0,471 & Valid \\
\hline & $\begin{array}{l}\text { 4. Kepercayaan akan keandalan } \\
\text { kerja (Y1.4) }\end{array}$ & 0,684 & Valid \\
\hline \multirow[t]{5}{*}{ Niat Beli $\left(\mathrm{Y}_{2}\right)$} & $\begin{array}{l}\text { 1. Mencari informasi mengenai } \\
\text { produk (Y2.1) }\end{array}$ & 0,614 & Valid \\
\hline & $\begin{array}{l}\text { 2. Mempertimbangkan untuk } \\
\text { membeli produk (Y2.2) }\end{array}$ & 0,692 & Valid \\
\hline & $\begin{array}{l}\text { 3. Rasa ingin tahu tentang produk } \\
\text { (Y2.3) }\end{array}$ & 0,584 & Valid \\
\hline & $\begin{array}{l}\text { 4. Rasa ingin mencoba produk } \\
\text { (Y2.4) }\end{array}$ & 0,613 & Valid \\
\hline & $\begin{array}{l}\text { 5. Rasa ingin memiliki produk } \\
\text { (Y2.5) }\end{array}$ & 0,427 & Valid \\
\hline
\end{tabular}

Sumber: Data diolah, 2017

Bila instrument memiliki nilai Alpha Cronbach lebih dari 0,6, maka suatu instrument dikatakan reliabel. Adapun hasil dari uji reliabilitas dapat ditunjukkan pada Tabel 5. berikut. 
Tabel 5.

Hasil Uji Reliabilitas

\begin{tabular}{lcc}
\hline \multicolumn{1}{c}{ Variabel } & Cronbach's Alpha & Keterangan \\
\hline Citra Merek & 0,691 & Reliabel \\
Kepercayaan & 0,765 & Reliabel \\
Niat Beli & 0,664 & Reliabel \\
\hline
\end{tabular}

Sumber: Data diolah, 2017

\section{Deskripsi Variabel Penelitian}

Penelitian responden terhadap pernyataan-pernyataan yang terkandung dalam kuesioner dapat ditunjukkan pada deskrpsi data penelitian. Jawaban responden dikelompokkan ke dalam kriteria sebagai berikut. Sangat buruk $(1,00-$ 1,79), buruk $(1,80-2,59)$, cukup baik $(2,60-3,39)$, baik $(3,40-4,19)$, sangat baik $(4,20-5,00)$. Berdasarkan hasil penelitian yang dilakukan dapat diketahui tanggapan responden melalui masing-masing indikator dari setiap variabel yaitu sebagai berikut. Variabel citra merek merupakan variabel eksogen dalam penelitian ini, yang diukur dengan menggunakan empat indikator untuk mengetahui jawaban responden. Hasil penilaian responden terhadap citra merek dapat dilihat lebih rinci pada Tabel 6.

\section{Tabel 6.}

Penilaian Responden terhadap Variabel Citra Merek

\begin{tabular}{|c|c|c|c|c|c|c|c|}
\hline \multirow{2}{*}{ Indikator } & \multicolumn{5}{|c|}{ Skor Jawaban } & \multirow{2}{*}{ Rata-rata } & \multirow{2}{*}{ Keterangan } \\
\hline & 1 & 2 & 3 & 4 & 5 & & \\
\hline Product Attributes (X1.1) & 0 & 11 & 21 & 33 & 45 & 4.02 & Baik \\
\hline Consumer Benefits (X1.2) & 0 & 10 & 25 & 34 & 41 & 3.96 & Baik \\
\hline Brand Personality (X1.3) & 1 & 14 & 22 & 28 & 45 & 3.93 & Baik \\
\hline Brand Attitude (X1.4) & 0 & 3 & 29 & 48 & 30 & 3.95 & Baik \\
\hline Total & & & & & & 3.97 & Baik \\
\hline
\end{tabular}


Tabel 6. menunjukkan penilaian responden terhadap indikator-indikator dari variabel citra merek. Hasil rata-rata tertinggi jawaban responden diperoleh dari indikator yang pertama yaitu product attributes dengan nilai rata-rata 4,02. Indikator tersebut menunjukkan sebanyak 11 responden menyatakan tidak setuju, 21 responden menyatakan cukup setuju, 33 responden menyatakan setuju, serta 45 responden menyatakan sangat setuju. Hasil rata-rata terendah jawaban responden diperoleh dari indikator yang ke-3 yaitu brand personality dengan nilai rata-rata 3,93. Indikator tersebut menunjukkan sebanyak 1 responden menyatakan sangat tidak setuju, 14 responden menyatakan tidak setuju, 22 responden menyatakan cukup setuju, 28 orang responden menyatakan setuju, dan 45 responden menyatakan sangat setuju. Data keseluruhan dari variabel citra merek, menunjukkan nilai rata-rata yakni 3,95. Nilai tersebut termasuk kriteria baik.

Variabel kepercayaan merupakan variabel intervening atau variabel mediasi dalam penelitian ini, yang diukur dengan menggunakan empat indikator untuk mengetahui jawaban responden pada Tabel 7.

Tabel 7.

Penilaian Responden terhadap Variabel Kepercayaan

\begin{tabular}{|c|c|c|c|c|c|c|c|}
\hline \multirow{2}{*}{ Indikator } & \multicolumn{5}{|c|}{ Skor Jawaban } & \multirow{2}{*}{ Rata-rata } & \multirow{2}{*}{ Keterangan } \\
\hline & 1 & 2 & 3 & 4 & 5 & & \\
\hline $\begin{array}{l}\text { Merasa aman menggunakan produk } \\
\text { (Y1.1) }\end{array}$ & 0 & 13 & 24 & 28 & 45 & 3.95 & Baik \\
\hline $\begin{array}{l}\text { Memberi kemudahan yang lebih jika } \\
\text { menggunakan produk (Y1.2) }\end{array}$ & 0 & 19 & 18 & 32 & 41 & 3.86 & Baik \\
\hline $\begin{array}{l}\text { Kepercayaan memiliki reputasi baik } \\
\text { (Y1.3) }\end{array}$ & 0 & 8 & 21 & 33 & 48 & 4.10 & Baik \\
\hline $\begin{array}{l}\text { Kepercayaan akan keandalan kerja } \\
\text { (Y1.4) }\end{array}$ & 0 & 11 & 19 & 25 & 55 & 4.13 & Baik \\
\hline Total & & & & & & 4.01 & Baik \\
\hline
\end{tabular}

Sumber: Data diolah, 2017 
Tabel 7. menunjukkan penilaian responden terhadap indikator-indikator dari variabel kepercayaan. Hasil rata-rata tertinggi jawaban responden diperoleh dari indikator yang ke-4 yaitu kepercayaan akan keandalan kerja dengan nilai rata-rata 4,13. Indikator tersebut menunjukkan sebanyak 11 responden menyatakan tidak setuju, 19 responden menyatakan cukup setuju, 25 responden menyatakan setuju, dan 55 responden menyatakan sangat setuju. Hasil rata-rata terendah jawaban responden diperoleh dari indikator yang ke-2 yaitu memberikan kemudahan yang lebih jika menggunakan produk dengan nilai rata-rata 3,86. Indikator tersebut menunjukkan sebanyak 19 responden menyatakan tidak setuju, 18 responden menyatakan cukup setuju, 32 responden menyatakan setuju, dan 41 responden menyatakan sangat setuju. Data keseluruhan dari variabel kepercayaan, menunjukkan nilai skor rata-rata total yaitu sebesar 4,01, secara umum responden memiliki kepercayaan baik terhadap produk smartphone Samsung.

Variabel niat beli merupakan variabel endogen dalam penelitian ini yang dipengaruhi oleh citra merek dan kepercayaan, yang diukur dengan menggunakan lima indikator untuk mengetahui jawaban responden pada Tabel 8.

Tabel 8.

Penilaian Responden terhadap Variabel Niat Beli

\begin{tabular}{|c|c|c|c|c|c|c|c|}
\hline \multirow{2}{*}{ Indikator } & \multicolumn{5}{|c|}{ Skor Jawaban } & \multirow{2}{*}{ Rata-rata } & \multirow{2}{*}{ Keterangan } \\
\hline & 1 & 2 & 3 & 4 & 5 & & \\
\hline Mencari informasi mengenai produk (Y2.1) & 0 & 12 & 22 & 31 & 45 & 3.99 & Baik \\
\hline $\begin{array}{l}\text { Mempertimbangkan untuk membeli produk } \\
\text { (Y2.2) }\end{array}$ & 0 & 11 & 15 & 29 & 55 & 4.16 & Baik \\
\hline Rasa ingin tahu tentang produk (Y2.3) & 0 & 9 & 29 & 33 & 39 & 3.93 & Baik \\
\hline Rasa ingin mencoba produk (Y2.4) & 0 & 15 & 27 & 27 & 41 & 3.85 & Baik \\
\hline Rasa ingin memiliki produk (Y2.5) & 0 & 3 & 23 & 33 & 51 & 4.20 & Sangat Baik \\
\hline Total & & & & & & 4.03 & Baik \\
\hline
\end{tabular}

Sumber: Data diolah, 2017 
Tabel 8. menunjukkan penilaian responden terhadap indikator-indikator dari variabel niat beli. Hasil rata-rata tertinggi jawaban responden diperoleh dari indikator yang ke-5 yaitu kepercayaan akan keandalan kerja dengan nilai rata-rata 4,20. Indikator tersebut menunjukkan sebanyak 3 responden menyatakan tidak setuju, 23 responden menyatakan cukup setuju, 33 responden menyatakan setuju, dan 51 responden menyatakan sangat setuju. Hasil rata-rata terendah jawaban responden diperoleh dari indikator yang ke-4 yaitu memberikan kemudahan yang lebih jika menggunakan produk dengan nilai rata-rata 3,85. Indikator tersebut menunjukkan sebanyak 15 responden menyatakan tidak setuju, 27 responden menyatakan cukup setuju, 27 responden menyatakan setuju, dan 41 responden menyatakan sangat setuju. Data keseluruhan dari variabel niat beli, menunjukkan nilai skor rata-rata total yaitu sebesar 4,03. Nilai tersebut termasuk kriteria baik, sehingga dapat dinyatakan bahwa secara garis besar responden memiliki persepsi baik terhadap niat beli produk smartphone Samsung.

\section{Hasil Analisis Jalur (Path Analysis)}

Tabel 9. melaporkan hasil dari analisis regresi yang telah dilakukan melalui software (SPSS) untuk menghitung koefisien path atau jalur.

Tabel 9.

Hasil Analisis Jalur Persamaan Regresi 1

\begin{tabular}{cccc}
\hline Model & R Square & $\begin{array}{c}\text { Standardized Coefficients } \\
\text { Beta }\end{array}$ & Sig. \\
\hline Citra Merek & 0,92 & 0,303 & 0,001 \\
\hline \multicolumn{2}{l}{ Sumber: Data diolah, 2017}
\end{tabular}

Jalur substruktur 1 yang disajikan Tabel 9. dapat memberikan informasi mengenai persamaan struktural yakni: 
$\mathrm{Y}_{1}=0,92 \mathrm{X}$

Tabel 10.

Hasil Analisis Jalur Persamaan Regresi 2

\begin{tabular}{lccc}
\hline \multicolumn{1}{c}{ Model } & $\boldsymbol{R}$ Square & $\begin{array}{c}\text { Standardized Coefficients } \\
\text { Beta }\end{array}$ & Sig. \\
\hline Citra Merek & 0,344 & 0,337 & 0,000 \\
Kepercayaan & & 0,338 & 0,000 \\
\hline \multicolumn{2}{l}{ Sumber: Data diolah, 2017}
\end{tabular}

Tabel 10. melaporkan mengenai hasil analisis jalur substruktural 2 dengan persamaan strukturalnya yakni:

$\mathrm{Y}_{2}=0,337 \mathrm{X}+0,388 \mathrm{Y}_{1}$

Dengan memperoleh informasi dari substruktural 1 dan model substruktural 2 disusun model diagram jalur akhir dengan terlebih dahulu dihitung nilai standard error nya yakni :

$\mathrm{e}_{1}=\sqrt{1-R 1^{2}}=\sqrt{1-0,92}=0,08$

$\mathrm{e}_{2}=\sqrt{1-R 2^{2}}=\sqrt{1-0,344}=0,656$

Hasil yang didapatkan dari penyusunan perhitungan diatas yakni error $\left(\mathrm{e}_{1}\right)$ sebesar 0,08 dan pengaruh error $\left(\mathrm{e}_{2}\right)$ sebesar 0,656.

Total koefisien determinasi yakni:

$$
\begin{aligned}
\mathrm{R}^{2} \mathrm{~m} & =1-\left(\mathrm{Pe}_{1}\right)^{2}\left(\mathrm{Pe}_{2}\right)^{2} \\
& =1-(0,08)^{2}(0,656)^{2} \\
& =1-(0,006)(0,430) \\
& =1-0,003 \\
& =0,997
\end{aligned}
$$


Dengan nilai dterminasi yakni 0,997 berarti bahwa sebanyak 99,7 persen variasi variabel niat beli dipengaruhi langsung oleh variasi citra merek dan variasi kepercayaan, sementara sisanya sebesar 0,3 persen tidak dapat dijelaskan dalam model atau terdapat adanya variabel lain yang mempengaruhi namun tidak tercantum dalam model yang dirumuskan.

\section{Pengaruh Parsial Variabel Penelitian}

Kriteria dalam menjelaskan bagaimana pengaruh antar masing-masing variabel yakni antara lain :

Apabila level sig. $\mathrm{t}<0,05$ maka Ho ditolak dan $\mathrm{H}_{1}$ diterima.

Apabila level sig. $\mathrm{t}>0,05$ maka Ho terima dan $\mathrm{H}_{1}$ tolak.

\section{Citra merek terhadap niat beli}

$\mathrm{H}_{0} \quad$ : Citra merek tidak berpengaruh signifikan terhadap niat beli

$\mathrm{H}_{1} \quad$ : Citra merek berpengaruh positif signifikan terhadap niat beli

Merujuk pada Tabel 7 dengan hasil analisis pengaruh citra merek terhadap niat beli diperoleh Sig. sebesar 0,000. Untuk nilai koefisien beta yang dihasilkan yakni mencapai 0,337 . Nilai Sig. yakni $0,000<0,05$ mengindikasikan bahwa citra merek berpengaruh positif dan signifikan terhadap niat beli secara parsial.

\section{Citra merek terhadap kepercayaan}

$\mathrm{H}_{0} \quad$ : Citra merek tidak berpengaruh signifikan terhadap kepercayaan

$\mathrm{H}_{1} \quad$ : Citra merek berpengaruh positif signifikan terhadap kepercayaan Merujuk pada hasil analisis Tabel 6 mengenai bagaimana pengaruh citra merek terhadap kepercayaan diperoleh Sig. t sebesar 0,001 dengan nilai koefisien beta sebesar 0,303. Dengan didaptkannya nilai Sig. $t \quad 0,001<0,05$ 
mangindikasikan bahwa citra merek berpengaruh positif dan signifikan terhadap kepercayaan secara parsial.

\section{Pengaruh kepercayaan terhadap niat beli}

$\mathrm{H}_{0} \quad$ : Kepercayaan tidak berpengaruh signifikan terhadap niat beli

$\mathrm{H}_{1} \quad$ : Kepercayaan berpengaruh positif signifikan terhadap niat beli

Hasil analisis yang dapat dilihat dari Tabel 7 yakni pengaruh kepercayaan terhadap niat beli diperoleh Sig. $\mathrm{t}$ sebesar 0,000 dengan nilai koefisien beta sebesar 0,388. Nilai Sig. t $0,000<0,05$ mengindikasikan bahwa kepercayaan berpengaruh positif dan signifikan terhadap niat beli secara parsial. Dengan keseluruhan nilai dapat digambarkan bagaimana diagram jalur seperti pada Gambar 2.

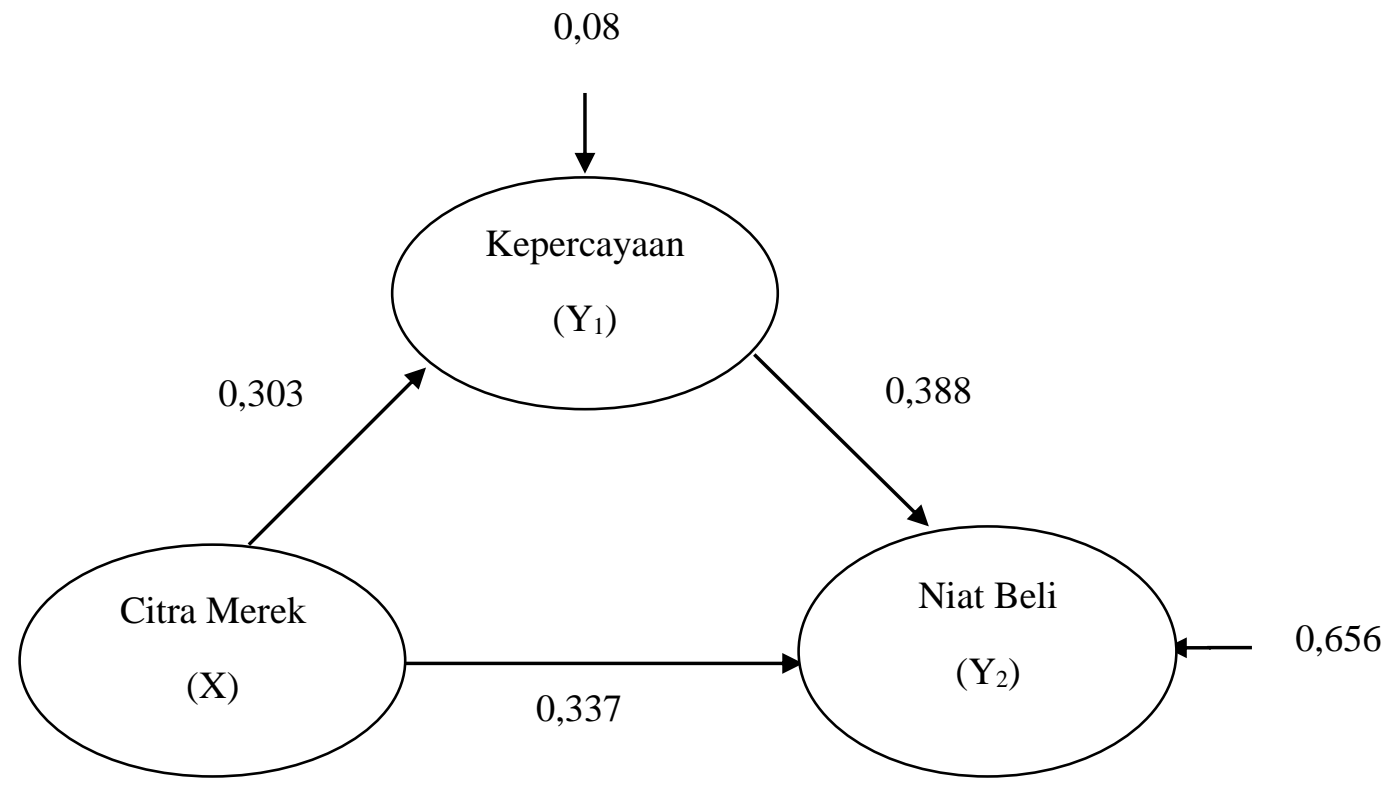

Gambar 2. Validasi Model Diagram Jalur Akhir

Merujuk pada Gambar 2. yang secara lengkap menginformasikan diagram jalur akhir dapat dihitung seberapa besar pengaruh langsung yang tercipta, 
Luh Gede Dian Anggara Putri, Peran Kepercayaan Memediasi Citra...

pengaruh tidak langsung serta pengaruh total antar variabel. Mengenai perhitungan secara menyeluruh diinformasikan oleh Tabel 11.

Tabel 11.

Pengaruh Langsung, Pengaruh Tidak Langsung, serta Pengaruh Total Citra Merek (X), Kepercayaan (Y1), dan Niat Beli (Y2)

\begin{tabular}{cccc}
\hline $\begin{array}{c}\text { Pengaruh } \\
\text { Variabel }\end{array}$ & $\begin{array}{c}\text { Pengaruh } \\
\text { Langsung }\end{array}$ & $\begin{array}{c}\text { Pengaruh Tidak Langsung } \\
\text { Melalui Kepercayaan } \\
(\mathbf{Y 1})=\left(\boldsymbol{\beta}_{\mathbf{1}} \mathbf{x} \boldsymbol{\beta}_{3}\right)\end{array}$ & $\begin{array}{c}\text { Pengaruh } \\
\text { Total }\end{array}$ \\
$\mathrm{X} \longrightarrow \mathrm{Y} 2$ & 0,337 & 0,102 & 0,439 \\
$\mathrm{X} \longrightarrow \mathrm{Y} 1$ & 0,303 & - & 0,303 \\
$\mathrm{Y} 1 \longrightarrow \mathrm{Y} 2$ & 0,388 & - & 0,388 \\
\hline
\end{tabular}

Sumber : Data diolah, 2017

Tabel 11. melaporkan bahwa pengaruh langsung variabel citra merek terhadap niat beli memiliki nilai koefisien beta sebesar 0,337 , sedangkan pengaruh tidak langsung yang dimediasi oleh kepercayaan menunjukkan nilai koefisiem beta sebesar 0,102. Hasil tersebut membuktikan bahwa kepercayaan memediasi hubungan citra merek terhadap niat beli dengan pengaruh total yang diperoleh sebesar 0,439 .

Pengujian dengan menggunakan Uji sobel dalam memberikan informasi mengenai signifikansi dari hubungan tidak langsung antara variabel eksogen dengan variabel endogen yang dimediasi oleh variabel intervening. Pengujian dilakukan untuk menjelaskan pengaruh variabel kepercayaan dalam memediasi hubungan antara pengaruh variabel citra merek terhadap niat beli pada produk smartphone Samsung di Kota Denpasar.

$$
Z=\frac{0,118}{\sqrt{0,303^{2} 0,049^{2}+0,388^{2} 0,141^{2}+0,141^{2} 0,049^{2}}}
$$




$$
\begin{aligned}
& Z=\frac{0,118}{\sqrt{0,000220+0,002993+0,000048}}=\frac{0,118}{\sqrt{0,003261}} \\
& Z=2,07
\end{aligned}
$$

Hasil signifikasi tidak langsung dalam perhitugan dengan uji sobel mengenai pengaruh citra merek terhadap niat beli melalui kepercayaan mendapatkan Z yakni 2,07 dimana memeiliki nilai melebihi dari 1,96. Dengan pengujian ini diketahui bahwa variabel kepercayaan secara signifikan dinilai dapat memediasi hubungan antar variabel yakni variabel citra merek dengan variabel niat beli.

Menjelaskan bagaimana pengaruh citra merek terhadap niat beli merupakan salah satu tujuan penelitian ini dilakukan. Dengan diperolehnya nilai koefisien beta sebesar 0,337 dengan tingkat signifikansi sebesar 0,000 (yakni kurang dari 0,05) yang berarti bahwa $\mathrm{H}_{1}$ diterima. Temuan dalam penelitian ini mempunyai arti bahwa variabel citra merek berpengaruh positif signifikan terhadap niat beli pada produk smartphone Samsung di Kota Denpasar, sehingga dengan semakin tinggi citra merek yang dimiliki oleh produk smartphone Samsung, maka semakin meningkatkan niat beli konsumen akan pembelian produk smartphone Samsung. Hasil penelitian ini sesuai dengan Mendrofa (2012) yang memperoleh temuan hasil bahwa citra merek memiliki pengaruh positif terhadap niat beli pada produk laptop yaitu merek HP. Hasil penelitian serupa juga diperoleh Wang dan Tsai (2014) yang menyatakan bahwa citra merek memiliki peranan dalam peningkatkan niat pembelian yang dimiliki konsumen. Selain itu, Wahyuni dan Suparna (2014) mendapatkan hasil yang serupa pada produk tas tiruan di Kota Denpasar. 
Dalam mencapai tujuan penelitian mengenai menjelaskan bagaimana pengaruh citra merek terhadap kepercayaan didapatkan nilai koefisien beta yakni 0,303 serta signifikansi sebesar 0,01 (kurang dari 0,05) berarti bahwa $\mathrm{H}_{2}$ diterima. Dengan diperolehnya nilai itu dapat dijelaskan bahwa variabel citra merek berpengaruh positif serta signifikan terhadap kepercayaan pada produk smartphone Samsung di Kota Denpasar, jadi semakin baik citra merek yang dimiliki oleh produk smartphone Samsung, maka akan meningkatkan kepercayaan konsumen terhadap produk smartphone merek Samsung. Hasil penelitian ini sesuai dengan Chen (2010) yang mendapatkan hasil bahwa kepercayaan dipengaruhi secara positif signifikan oleh bagaimana citra merek yang dimiliki suatu produk. Penelitian yang memperoleh hasil serupa juga dilakukan oleh Lee (2011) yang mendapatkan hasil bahwa kepercayaan merek dipengaruhi positif dan signifikan oleh seberapa tinggi citra yang dimiliki suatu merek tertentu. Citra dan Santoso (2016) juga mendapatkan hasil serupa dengan penelitian-penelitian tersebut.

Untuk dapat menjelaskan bagaimana pengaruh kepercayaan terhadap niat beli didapatkan hasil dari nilai koefisien beta yakni 0,388 serta signifikansi 0,000 (kurang dari 0,05) yakni memiliki arti bahwa variabel kepercayaan berpengaruh positif signifikan terhadap niat beli pada produk smartphone Samsung di Kota Denpasar, jadi semakin tinggi kepercayaan yang dimiliki konsumen terhadap produk smartphone Samsung, maka akan semakin meningkatkan niat beli konsumen dalam mengomsumsi produk smartphone Samsung. Albari dan Liriswati (2004), Arista dan Astuti (2011), Nusarika dan Purnami (2015), Citra 
dan Santoso (2016) yang mendapatkan hasil bahwa kepercayaan berpengaruh signifikan terhadap niat beli. Variabel kepercayaan merek mempengaruhi minat pembelian dengan hasil menunjukkan nilai positif signifikan. Kepercayaan konsumen terhadap merek jelas mempengaruhi niat beli. Namun hasil penelitian ini berbeda dengan hasil penelitian yang dilakukan oleh Rizanata (2014) serta Irandust dan Bamdad (2014) yang memperoleh hasil bahwa variabel kepercayaan tidak memiliki pengaruh yang signifikan terhadap variabel niat beli.

Dalam tahap pengujian hipotesa keempat ini menggunakan Uji Sobel diperoleh hasil Z sebesar 2,07 melebihi 1,96 dengan signifikansi 0,000 lebih besar dibandingkan 0,05 yang mengindikasikan variabel penelitian kepercayaan secara positif serta signifikan memediasi pengaruh citra merek terhadap niat beli dan dapat disimpulkan bahwa $\mathrm{H}_{4}$ diterima. Hasil ini didukung oleh Meskara et al. (2013), Bastian (2014), Indraswari dan Pramudana (2014) menyatakan bahwa kepercayaan memediasi secara positif signifikan pengaruh citra merek terhadap niat beli. Citra dan Santoso dalam penelitiannya yang berjudul Analisi Pengaruh Kualitas Produk dan Citra Merek Terhadap Keputusan Pembelian Cetakan Continuous Form Melalui Kepercayaan memperoleh hasil bahwa memang benar kepercayaan memediasi positif signifikan variabel citra merek terdahap keputusan pembelian. Citra merek yang baik maka akan memunculkan kepercayaan konsumen pada suatu merek yang pada akhirnya akan menimbulkan niat beli. 


\title{
Implikasi Hasil Penelitian
}

\author{
Implikasi Teoritis
}

Berdasarkan penelitian yang telah dilakukan dapat diketahui bahwa secara teoretis, penelitian ini mendukung beberapa teori yang telah ada sebelumnya. Penelitian ini diharapkan dapat menjadi suatu hal baru untuk penelitian yang berhubungan dengan variabel citra merek, kepercayaan, dan niat beli. Pengolahan data dilakukan dengan teknik analisis jalur (path analysis) untuk memperkirakan hubungan antara variabel-variabel yang telah ditetapkan sebelumnya berdasarkan teori. Penelitian ini juga menggunakan uji sobel untuk menguji kekuatan pengaruh tidak langsung variabel citra merek $(\mathrm{X})$ terhadap variabel niat beli $\left(\mathrm{Y}_{2}\right)$ melalui variabel kepercayaan $\left(\mathrm{Y}_{1}\right)$. Hasil penelitian ini diharapkan dapat digunakan untuk memperkaya referensi yang berkaitan dengan citra merek, kepercayaan dan niat beli.

Implikasi Praktis

Hasil penelitian ini digunakan sebagai masukan bagi pihak smartphone Samsung untuk dapat meningkatkan citra merek produk di benak konsumen melalui kepercayaan sehingga dapat meningkatkan niat beli guna membeli produk smartphone Samsung. Strategi yang dapat dilakukan yaitu dengan memperhatikan masukan dari konsumen, membuat fitur baru yang dibutuhkan konsumennya agar semua kebutuhan konsumennya dapat terpenuhi.

\section{Keterbatasan Penelitian}

Beberapa keterbatasan penelitian ini yang dapat disususn dari penelitian ini adalah sebagai berikut yaitu lingkungan dapat berubah setiap saat sedangkan 
penelitian ini dilakukan dalam jangka waktu terbatas sehingga penting untuk melakukan penelitian ini kembali. Terbatasnya ruang lingkup serta jumlah responden dalam penelitian yang terbatas menyebabkan hasil dari penelitian tidak dapat digeneralisasikan secara langsung untuk dapat mewakili konsumen di luar wilayah penelitian.

\section{SIMPULAN DAN SARAN}

\section{Simpulan}

Simpulan yang dapat disusun berdasarkan hasil pembahasan adalah sebagai berikut. Citra merek memiliki pengaruh yang positif signifikan terhadap niat beli pada produk smartphone Samsung di Kota Denpasar. Jadi, semakin baik citra merek produk smartphone Samsung di benak konsumen, maka akan semakin tinggi pula niat konsumen untuk melakukan pembelian. Citra merek berpengaruh positif signifikan terhadap kepercayaan konsumen pada produk smartphone Samsung di Kota Denpasar. Jadi semakin baik citra merek produk smartphone Samsung di benak konsumen, menyebabkan tinggi pula tingkat kepercayaan konsumen terhadap smartphone Samsung. Kepercayaan berpengaruh positif signifikan terhadap niat beli konsumen pada smartphone Samsung di Denpasar. Jadi apabila tingkat kepercayaan konsumen tinggi akan smartphone Samsung, maka akan semakin tinggi pula niat konsumen untuk melakukan pembelian. Kepercayaan secara signifikan memediasi pengaruh citra merek terhadap niat beli pada produk smartphone Samsung di Denpasar, hal ini berarti citra merek yang dimiliki oleh smartphone Samsung akan dapat memediasi kepercayaan konsumen sehingga memunculkan niat untuk membeli produk smartphone Samsung. 


\section{Saran}

Yang dapat diberikan kepada pihak-pihak yang memerlukan berdasarkan hasil analisis dan simpulan adalah sebagai berikut. Pihak smartphone Samsung agar berupaya memberikan manfaat produk yang dapat diandalkan sehingga memberikan rasa aman dan kemudah saat menggunakan produk smartphone Samsung. Pihak smartphone Samsung agar melakukan inovasi dan pengembangan fitur guna memenuhi kebutuhan konsumen yang kian beragam. Reputasi yang baik juga dibutuhkan untuk meningkatkan niat beli konsumen. Penelitian di masa mendatang, perlu memperhitungkan agar menanbahkan variabel lain yang mempengaruhi niat beli sehingga dapat menganalisi faktorfaktor yang mempengaruhi niat beli konsumen lebih lanjut.

\section{REFERENSI}

Albari dan Liriswati, A. 2004. Analisis Minat Beli Konsumen Sabun Cair Lux, Biore dan Lifebuoy di Kotamadya Yogyakarta Ditinjau dari Pengaruh Sikapnya Setelah Melihat Iklan di Televisi dan Norma Subyektif. Jurnal Siasat Bisnis, 9 (2), 215-239.

Asosiasi Penyelenggara Jasa Internet Indonesia. 2016. https://www.apjii.or.id/survei2016 (diunduh tanggal 25 September 2017).

Arista, E.D. dan Astuti, S.R.T. 2011. Analisis Pengaruh Iklim, Kepercayaan Merek, dan Citra Merek Terhadap Minat Beli Konsumen. Aset, 13 (1), 3745.

Bagram, M.M.M. and Khan, S. 2012. Attaining Customer Loyal! The Role of Consumer Attitude and Consumer Behaviors. International Reviews of Management and Business Research, 1 (1), 1-8.

Bastian, D.A. 2014. Analisa Pengaruh Citra Merek (Brand Image) dan Kepercayaan Merek (Brand Trust) Terhadap Loyalitas Merek (Brand Loyalty) ADES PT. Ades Alfindo Putra Setia. Jurnal Manajemen Pemasaran Petra. 2 (1), 1-9.

Chen, Y.S. 2010. The Drivers of Green Brand Equity: Green Brand Image, Green Satisfactions, and Green Trust. Journal of Business Ethic, 2 (93), 307-319. 
Chen, Y.S. and Chang, C.H. 2012. Enhance Green Purchase Intention-The Role Of Green Perceived Value, Green Perceived Risks, And Green Trust. Management Decisions, 50 (3), 502-520.

Citra, T. dan Santoso, S.B. 2016. Analisi Pengaruh Kualitas Produk dan Citra Merek Terhadap Keputusan Pembelian Cetakan Continuous Form Melalui Kepercayaan. Jurnal Studi Manajemen dan Organisasi. 13 (16), 67-79.

Dewi, W.S., Hasiolan, L.B., dan Minarsih, M.M. 2016. Pengaruh Kualitas Produk, Kepercayaan Terhadap Keputusan Pembelian Dengan Kepuasan Konsumen Sebagai Variabel Intervening. Journal Of Management, 2 (2), 119.

Dharma, N.P.S.A. dan Sukaatmadja, I.P.G. 2015. Pengaruh Citra Merek, Kesadaran Merek, dan Kualitas Produk Terhadap Keputusan Membeli Produk Apple. E-Jurnal Manajemen Unud, 4 (10), 3228-3255.

Efriandy, I. 2013. Kualitas Pelayanan dan Kepercayaan Nasabah (Studi pada Nasabah Tabungan PT Bank Aceh di Kota Blangpidie). Jurnal Ekonomi Manajemen Dan Bisnis, 1 (2), 171-182.

Fure, H. 2013. Lokasi, Keberagaman Produk, Harga, Dan Kualitas Pelayanan Pengaruhnya terhadap Minat Beli pada Pasar Tradisional Calaca. Jurnal Emba, 1 (3), 273-283.

Gunawan, F. A. dan Dharmayanti, D. 2014. Analisis Pengaruh Iklan Televisi dan Endorser terhadap Purchase Intention Pond Men dengan Brand Awarenes sebagai Variabel Intervening. Jurnal Manajemen Pemasaran Petra, 2 (1), 114.

Ika, N dan Kustini. 2011. Experiential Marketing, Emotional Brandings, And Brand Trust And Their Effect On Loyalty On Honda Motorcycle Product. Journal of Economic, Busines and Accountancy Ventura, 14 (1), 19-28.

Indrawari, N.M.M. dan Pramudana, K.A.S. 2014. Pengaruh Kredibilitas Celebrity Endorses dan Kewajaran Harga Terhadap Niat Beli Konsumen Wanita pada Online Shops Produk Pakaian. E-Jurnal Manajemen, 3 (4), 938-955.

International Data Corpuration. 2017.

https://www.idc.com/promo/smartphone-market-share/vendor.2017 (diunduh tanggal 25 September 2017).

Irandust, M. and Bamdad, N. 2014. The Role Of Customer's Believability and Attitude In Green Purchase. Journal of Bussiness and Management Review, 3 (7), pp.242-248. 
Kotler, P. and Keller, K. L. 2009. Manajemen Pemasaran. Edisi 12. Jilid 1. Alih bahasa: Benyamin Molan. Jakarta: Indek.

Kristianto, P. H. dan Junaedi, S. 2014. Peran Kepercayaan Merek Sebagai Variabel Mediasi antara Karakteristik Merek dengan Loyalitas Merek Produk Cinderamata Dagadu Djokdja. Jurnal Manajemen, 12 (3), 1-14.

Lee, H. M. 2011. Brand Image Strategy Affects Brand Equity After M\&A. European Journal of Marketing, 45 (7/8), 1091 - 1111.

Ling, K.C., Chai, L.T., and Piew, T.H. 2010. The Effects of Shopping Orientations, Online Trust and Prior Online Purchase Experience toward Customers' Online Purchase Intention. International Business Research, 3 (3), 63-76.

Mendrofa, Y.B. 2012. Effect Of Products Knowledges and Brand Image To Purchase Intention With HP Laptop Brand Price Discounts As Variable Moderated in Surabaya. Jurnal Ilmiah Mahasiswa Manajemen, 21 (4), 1-6.

Mowen, J.C., dan Michael, M. 2002. Perilaku Konsumen. Jilid 1, Jakarta : Erlangga.

Nusarika, K.L.A. dan Purnami, N.M. 2015. Pengaruh Persepsi Harga, Kepercayaan, dan Orientasi Belanja Terhadap Niat Beli Secara Online. EJurnal Manajemen Unud, 4 (8), 2380-2406.

Permadi, P.C., Kumadji, S., dan Kusumawati, A. 2014. Pengaruh Citra Merek Terhadap Word Of Mouth dan Keputusan Pembelian (Survei pada Konsumen Dapoer Mie Galau Jalan Selorejo 83 Malang). Jurnal Administrasi Bisnis (JAB), 10 (1), 1-7.

Rizan, M. Saidani, B. dan Sari, Y. 2012. Pengaruh Brand Image dan Brand Trust Terhadap Brand Loyalty The Botol Sosro. Jurnal Riset Manajemen Sains Indonesia (JRMSI), 3 (1), 1-17.

Rizanata, M.F. 2014. Pengaruh Kepercayaan Pelanggan terhadap Word Of Mounth, Niat Beli Dan Retensi Pelanggan Gerai Indomaret di Surabaya. Journal Of Bussiness And Banking, 4 (1), 31-42.

Setiadi, N. J. 2008. Perilaku Konsumen, Jakarta: PT Kencana.

Shah, S., Hussain, S., Aziz, J., Jaffari, A.R., Waris, S., Ejaz, W., Fatima, M. and Sherazi, S.K. 2012. The Impact of Brands on Consumer Purchase Intentions. Asian Journal of Business Management, 4 (2), 105-110.

Sugiyono. 2017. Metode Penelitian Administrasi. Bandung: Alfabeta. 
Surachman, S.A. 2008. Dasar-Dasar Manajemen Merek. Edisi Pertama.Malang Bayumedia Publishing.

Tariq, M.I., Nawaz, M.R., Nawaz, M.M., and Butt, H.A. 2013. Custome Perceptions about Branding and Purchase Intention: A Study of FMCG in an Emerging Market. Journal of Basic and Applied Scientific Research, 3 (2), 340-347.

Top Brand Award. 2017. http://www.topbrand-awrd.com/top-brandsurvey/survey-result/top_brand_index_2017_fase_1 (diunduh tanggal 25 September 2017).

Wang, Y.H., and Tsai, C.F. 2014. The Relationship Between Brand Image and Purchase Intention: Evidences from Award Winning Mutual Fund. The International Journals of Busines and Finance Research, 8 (2), 27-40.

Wahyuni, N.L.G., dan Suparna, G. 2014. Pengaruh Citra merek dan Product Knowledge Terhadap Niat membeli Produk Tas Tiruan di Kota Denpasar. EJurnal Manajemen Universitas Udayana, 3 (4), 1022-1034.

Walley, K., Custance, P. and Taylor, S. 2007. The Importances of Brand in the Industrial Purchase Decision: a Cases Study of the UK Tractors Market. Journal of Business \& Industrial Marketing, 22 (6), 383-393.

Wang, Y.H., and Tsai, C.F. 2014. The Relationship Between Brand Image and Purchase Intention: Evidence from Award Winning Mutual Fund. The International Journals of Busines and Finance Research, 8 (2), 27-40. 